\title{
ANALISIS PENDAPATAN RUMAH TANGGA PETANI CENGKEH DI DESA TULAP KECAMATAN KOMBI KABUPATEN MINAHASA
}

\author{
Meidita Christine Kerap \\ Caroline B. D. Pakasi \\ Mex L. Sondakh
}

\begin{abstract}
This study aims to identify the source of household income of clove farmers in Tulap Village Kombi Sub-district of Minahasa Regency. This study was conducted from February to March 2018. The data collection method used were primary data and secondary data. Primary data was obtained directly from the source through a survey by using questionnaires as the main instrument to collect data to clove farmers who also plant other crops such as peanuts, corn, and caberawit. The secondary data includ data published by the Central Bureau of Statistics as well as various literature related to the research topic. The results showed that the source of income of clove farmer household in Tulap Village, Kombi Subdistrict consisted of clove farming, other farming business, and those outside of farming business. The income pources outside farming were divided into farmers' and household members of farmers income. The highest income of clove farmers was obtained by the farmers' households, which meet the four sources of income, namely from clove farming, other farming, non-farm income and family members income with an average of Rp. 113,476,641 per year with a percentage of 15.22\%. This proves if clove farmers have other farming businesses, have jobs outside the farm business, and household members have jobs and contribute to household income, the household will be more prosperous. "Ghmk*.
\end{abstract}

Keywords: household income, clove farmer, Tulap Village, Kombi Sub-District, Minahasa Regency

\begin{abstract}
ABSTRAK
Penelitian ini bertujuan untuk mengidentifikasi sumber pendapatan rumah tangga petani cengkeh di Desa Tulap Kecamatan Kombi Kabupaten Minahasa. Penelitian ini dilakukan dari bulan Februari sampai bulan Maret 2018. Metode pengumpulan data menggunakan data primer dan data sekunder. Data primer diperoleh langsung dari sumbernya melalui survei dengan menggunakan kuesioner sebagai instrumen utama untuk mengumpulkan data kepada petani cengkeh yang menanam tanaman lainnya seperti kacang tanah, jagung, dan caberawit. Sedangkan data sekunder meliputi data yang di publikasikan Badan Pusat Statistik serta berbagai literatur yang berkaitan dengan topik penelitian. Hasil penelitian menunjukkan bahwa sumber pendapatan rumah tangga petani cengkeh di Desa Tulap Kecamatan Kombi terdiri dari usaha tani cengkeh, usaha tani lainnya, dan mata pencahariam di luar usaha tani. Mata pencaharian di luar usaha tani terbagi atas pendapatan petani dan anggota rumah tangga petani di luar usaha tani. pendapatan rumah tangga petani cengkeh tertinggi di peroleh oleh rumah tangga petani yang memenuhi empat sumber pendapatan yaitu dari usaha tani cengkeh, usaha tani lainnya, pendapatan di luar usaha tani dan pendapatan anggota keluarga yaitu dengan rata-rata sebesar Rp. 113.476.641 per tahun dengan persentase $15,22 \%$. Hal ini membuktikan apabila petani cengkeh memiliki usaha tani lainnya, memiliki pekerjaan di luar usaha tani, dan anggota rumah tangganya memiliki pekerjaan dan turut berkontribusi dalam pendapatan rumah tangga maka rumah tangga tersebut akan semakin sejahtera. ${ }^{*}$ Ghmk*
\end{abstract}

Kata kunci: pendapatan rumah tangga, petani cengkeh, Desa Tulap, Kecamatan Kombi, Kabupaten Minahasa 


\section{PENDAHULUAN}

\section{Latar Belakang}

Sektor Pertanian merupakan sektor yang paling prospektif dalam menopang perekonomian nasional. Bukti bahwa sektor pertanian adalah sektor yang prospektif dimana kebutuhan pangan di dalam negeri dari tahun ke tahun semakin meningkat seiring dengan peningkatan jumlah penduduk (Saragih, 2004). Peningkatan produksi yang harus seimbang dengan laju pertumbuhan penduduk dapat dicapai melalui peningkatan pengelolaan usaha tani secara intensif. Dengan adanya peningkatan produktifitas, maka pendapatan dan kesejahteraan rumah tangga petani dapat meningkat.

Sebagian besar masyarakat di Kabupaten Minahasa memiliki lapangan pekerjaan utama sebagai petani. Hal ini dapat dilihat dari keseluruhan jumlah total penduduk di kabupaten Minahasa berjumlah 136.369 jiwa, dan yang berprofesi sebagai petani berjumlah 43.494 jiwa (BPS, 2016). Berikut adalah Tabel 1 jumlah penduduk berumur 15 tahun ke atas menurut lapangan pekerjaan utama dan jenis kelamin di kabupaten Minahasa, 2015.

Tabel 1. Jumlah penduduk berumur 15 tahun ke atas menurut lapangan pekerjaan utama dan jenis kelamin di kabupaten Minahasa, 2015.

\begin{tabular}{|c|c|c|c|c|}
\hline \multirow[t]{2}{*}{ No } & \multirow{2}{*}{$\begin{array}{c}\text { Lapangan } \\
\text { Pekerjaan } \\
\text { Utama }\end{array}$} & \multicolumn{2}{|c|}{ Jenis Kelamin } & \multirow[t]{2}{*}{ Jumlah } \\
\hline & & Laki-laki & Perempuan & \\
\hline 1 & $\begin{array}{l}\text { Pertanian, } \\
\text { Perkebunan, } \\
\text { Kehutanan, } \\
\text { Perburuan, dan } \\
\text { Perikanan }\end{array}$ & 38.081 & 5.413 & 43.494 \\
\hline 2 & $\begin{array}{l}\text { Industri } \\
\text { (Pertambanga, } \\
\text { Industri, } \\
\text { Konstruksi, } \\
\text { Listrik, Gas, } \\
\text { dan Air) }\end{array}$ & 18.490 & 1.773 & 20.263 \\
\hline 3 & $\begin{array}{l}\text { Jasa } \\
\text { (Perdagangan, } \\
\text { Rumah Makan, } \\
\text { Lembaga } \\
\text { Keuangan, Real } \\
\text { Estate, Usaha } \\
\text { Persewaan) }\end{array}$ & 37.868 & 34.744 & 72.612 \\
\hline & Jumlah & 94.439 & 41.930 & 136.369 \\
\hline
\end{tabular}

Sumber: Survey angkatan kerja Nasional Agustus dalam BPS, 2016
Kabupaten Minahasa merupakan daerah dengan luas lahan pertanian sebesar $52.933 \mathrm{Ha}$ yang terbagi dalam tiga jenis penggunaan lahan yaitu sawah, kebun/tegal, dan ladang/huma. Sawah memiliki luas 7.570 Ha, Kebun/tegal memiliki luas $29.064 \mathrm{Ha}$, dan ladang/Huma memiliki luas 16.299 Ha (Dinas Pertanian Kabupaten Minahasa, 2016). Dari data tersebut, kebun/tegal memiliki luasan terbesar dalam penggunaan lahan pertanian di kabupaten Minahasa.

Kecamatan Kombi merupakan wilayah dengan penggunaan lahan kebun/tegal terluas yakni 5.725 Ha. Jumlah penduduk di kecamatan Kombi menurut BPS Minahasa Tahun 2016 sebanyak 9916 jiwa. Ada tiga belas desa yang berada di Kecamatan Kombi. Desa Tulap merupakan salah satu desa yang berada di Kecamatan Kombi yang sebagian besar penduduk berprofesi sebagai petani. Di Desa Tulap, terdapat bermacam-macam profesi, Petani merupakan profesi terbanyak yang dipilih penduduk Desa Tulap. Ada bermacammacam komoditi yang berada di desa ini, termasuk didalamnya yaitu cengkeh, pala, kelapa, vanili, kacang tanah, cabe rawit dan jagung.

Pada masa yang lalu petani Cengkeh yang berada di desa ini dikatakan sukses apalagi mereka yang memiliki lahan yang luas, bahkan dulu dikatakan petani yang baru saja memanen cengkeh sekembalinya dari kota setelah menjual hasil panennya pasti pulang dengan motor atau mobil baru. Pada saat itu pula kejayaan petani cengkeh masih tinggi sehingga beberapa penduduk ada yang berprofesi sebagai pegawai beralih profesi demi menjadi petani cengkeh karena mereka yakin hasil panen akan lebih dari cukup untuk memenuhi kebutuhan hidup seharihari, sehingga tidak perlu mencari pekerjaan lain. Namum berbeda dengan saat ini, ketika beberapa tahun lalu terjadi kemarau yang berkepanjangan menyebabkan banyak kebun yang terbakar dan tanah yang menjadi tandus. Banyak pohon cengkeh yang tidak berbuah atau hanya berbuah sedikit dengan waktu yang tidak menentu yang mengakibatkan menurunnya hasil panen yang sangat berdampak buruk bagi kehidupan petani cengkeh, terjadi kerugian yang besar sehingga perekonomian dari petani cengkeh sangat menurun. 
Harga cengkeh yang tidak menentu juga menjadi faktor utama dalam menurunnya pendapatan rumah tangga petani cengkeh. Fluktuasi harga cengkeh tahun 2014 sampai 2018 di Desa Tulap Kecamatan Kombi Kabupaten Minahasa di tunjukkan pada Tabel 2 di bawah ini.

\section{Tabel 2. Fluktuasi harga cengkeh}

\begin{tabular}{clr}
\hline No & Tahun & Harga $(\mathbf{R p} / \mathbf{K g})$ \\
\hline 1. & 2014 & $150.000-170.000$ \\
2. & 2015 & $120.000-150.000$ \\
3. & 2016 & $80.000-90.000$ \\
4. & 2017 & $100.000-110.000$ \\
5. & 2018 & $98.000-105.000$ \\
\hline
\end{tabular}

Sumber: Laporan Desa Tulap

Karena itu para petani cengkeh sebagian mulai mencari pekerjaan tambahan, sebagian memulai menanam tumbuhan lainnya seperti kacang tanah, jagung, dan caberawit, dan petani cengkeh lainnya bahkan sudah menjual atau menggadaikan lahan kebunnya, meskipun sebagaian petani masih bertahan sebagai petani cengkeh saja.

Tolak ukur yang sangat penting untuk melihat kesejahteraan petani adalah pandapatan rumah tangga petani, sebab beberapa aspek dari kesejahteraan tergantung pada tingkat pendapatan rumah tangga petani. Besarnya pendapatan rumah tangga petani itu sendiri akan mempengaruhi kebutuhan dasar yang harus dipenuhi yaitu, pangan, sandang, papan, kesehatan dan lapangan kerja.

Dengan berbagai penjelasan tersebut, penulis merasa perlu melakukan penelitian mengenai tingkat pendapatan petani cengkeh yang saat ini juga menanam komoditi tanaman lainnya di Desa Tulap, Kecamatan Kombi, Kabupaten Minahasa.

\section{Rumusan Masalah}

Berdasarkan uraian pada latar belakang maka di rumuskan permasalahan penelitian yaitu darimana sumber-sumber pendapatan rumah tangga petani cengkeh dan berapa besar pendapatan rumah tangga petani cengkeh, serta bagaimana strukturnya.

\section{Tujuan Penelitian}

Tujuan penelitian ini adalah untuk mengetahui:

1. Sumber-sumber pendapatan rumah tangga petani cengkeh.

2. Besarnya pendapatan rumah tangga petani cengkeh dan untuk mengetahui struktur pendapatan rumah tangga petani cengkeh.

\section{METODE PENELITIAN}

\section{Waktu dan Tempat Penelitian}

Penelitian ini dilaksanakan pada bulan Februari sampai April 2018 di Desa Tulap, Kecamatan Kombi Kabupaten Minahasa.

\section{Metode Penelitian}

Penelitian ini menggunakan metode kuantitatif. Metode penelitian kuantitatif yang digunakan yaitu metode survei. Metode survei adalah metode penelitian yang menggunakan kuesioner sebagai instrumen utama untuk mengumpulkan data. Metode ini digambarkan sesuai keadaan teraktual. Data tersebut disusun, dianalisis, dijelaskan, kemudian diambil kesimpulannya.

\section{Metode Pengambilan Sampel}

Metode yang digunakan untuk pengambilan sampel dalam penelitian ini adalah metode yang dipilih secara sengaja (purposive sampling). Petani di Desa Tulap yang menjadi sampel adalah petani cengkeh yang memiliki usaha tani lain atau memiliki pekerjaan di luar usaha tani.

Teknik pengambilan data dilakukan dengan menentukan sampel jumlah rumah tangga petani cengkeh yang memiliki komoditi tanaman lain di Desa Tulap. Jumlah rumah tangga petani cengkeh yang berada di desa Tulap yaitu 249 rumah tangga petani dari total 356 rumah tangga. Dan rumah tangga petani cengkeh yang menanam komoditi lain yaitu sebanyak 154 rumah tangga petani (Laporan desa Tulap, 2017).

Jumlah sampel penelitian diambil secara acak 30\% dari jumlah rumah tangga petani cengkeh yang menanam komoditi lain (kelapa, pala, kacang tanah, jagung, cabe rawit).

Jumlah sampel $=30 \% \times 154=46$ Rumah Tangga Petani. 


\section{Metode Pengumpulan Data}

Data yang akan digunakan dalam penelitian ini berupa data primer dan data sekunder. Data Primer adalah data yang diperoleh langsung di lapangan. Data Primer meliputi karakteristik petani dan pendapatan yang diperoleh secara langsung dari rumah tangga petani cengkeh. Data Sekunder meliputi data yang di publikasikan Badan Pusat Statistik serta berbagai literatur yang berkaitan dengan topik penelitian.

\section{Konsepsi Pengukuran Variabel}

Indikator variabel penelitian yang dikaji dalam penelitian ini yaitu:

1. Karakteristik Rumah Tangga Petani Cengkeh
a. Karakteristik Petani Cengkeh
b. Jumlah Anggota Rumah Tangga Petani Cengkeh
c. Jenis Mata Pencaharian lainnya

2. Produksi
a. Komoditi cengkeh ( $\mathrm{kg} / \mathrm{ha} / \mathrm{tahun})$
b. Komoditi selain cengkeh $(\mathrm{kg} / \mathrm{ha} / \mathrm{tahun})$

3. Pendapatan Rumah Tangga Petani

Pendapatan rumah tangga petani pada penelitian ini dihitung berdasarkan pendapatan petani yang menanam komoditi lain dan memiliki mata pencaharian diluar usaha tani dan pendapatan dari anggota keluarga lainnya.

4. Pendapatan Usaha Tani

Pendapatan usaha tani diperoleh dari pendapatan hasil wawancara, bukan di tuangkan dari produksi, harga, dan biayabiaya.

\section{Metode Analisis Data}

Dalam analisis data penelitian ini di dukung oleh data kuantitatif dan kualitatif, untuk mengontrol informasi yang bersifat kualitatif diperlukan informasi data kuantitatif sedangkan untuk memperjelas data kuantitatif diperlukan data kualitatif.

Sumber pendapatan petani berasal dari pendapatan pertanian dan non pertanian. Pendapatan pertanian yaitu pendapatan dari komoditi cengkeh, kelapa, pala, jagung, kacang tanah, dan cabe rawit. Sedangkan pendapatan non pertanian yaitu perdagangan dan jasa.
Menurut Kadarsan (1995) dalam Soekartawi (2011), pendapatan sering sama artinya dengan keuntungan, petani akan memperoleh keuntungan apabila selisih total penerimaan dengan total biaya adalah positif. Total penerimaan merupakan jumlah produksi yang dijual pada waktu penjualan dari harga yang diterima. Total penerimaan sering disebut total penjualan atau pendapatan kotor.

Secara matematis untuk menghitung pendapatan rumah tangga petani dapat dirumuskan sebagai berikut:

Pendapatan rumah tangga petani :

$$
\mathrm{Yt}=\mathrm{Yk}+\mathrm{Yl}+\mathrm{Yd}
$$

Keterangan:

Yt $=$ Pendapatan rumah tangga $(\mathrm{Rp} / \mathrm{th})$

$\mathrm{Yk}=$ Pendapatan rumah tangga petani cengkeh $(\mathrm{Rp} / \mathrm{th})$

$\mathrm{Yl}=$ Pendapatan usahatani lainnya $(\mathrm{Rp} / \mathrm{th})$

$\mathrm{Yd}=$ Pendapatan di luar usahatani $(\mathrm{Rp} / \mathrm{th})$

\section{HASIL DAN PEMBAHASAN}

\section{Deskripsi Wilayah Penelitian}

\section{Sejarah Desa Tulap}

Negeri/Perkampungan Tulap sudah ada sebelum adanya pemerintahan yang tetap. Pada pertengahan abad 19 yang masih mengenal nenek moyang (opo-opo), berasal dari Toulour (Tondano) mereka melarikan diri ke Tondano Pante karena pada saat itu terjadi peperangan atas Tondano dan Tomohon. Nenek moyang (opo-opo) pada saat itu merombak hutan dan bekerja secara gotong royong sehingga membentuk satu perkampungan.

Opo-opo tersebut berunding untuk menetapkan seorang pemimpin pemerintahan. Karena begitu terkenalnya Tonaas Mawikere di Tomohon maka beberapa Opo-Opo menjemputnya. Setelah Tonaas Mawikere tiba maka dilakukan penunjukan ketiga yang tertua dari ke 20 Opo yaitu : "Opo Rarung, Opo Taas, Opo Maapi". Dari ketiga Opo inilah dipilih siapa yang akan memimpin negeri/ perkampungan yang baru ini. Cara pemilihannya adalah dengan didahului pelepasan Ayam Jantan dan harus berkokok. Kemudian dilaksanakan persyaratan yang harus dilakukan oleh ketiga Opo ini. Dimulai dari Opo Rarun dan Opo Taas dan kedua 
Opo ini ayam mereka tidak berkokok. Pelepasan ayam ketiga di lakukan oleh Opo Maapi dan waktu dilepas ayam dari Opo Maapi langsung berkokok yang bertanda dan ditetapkannya Opo Maapi oleh Tonaas Mawikere sebagai pemimpin negeri/perkampungan yang baru ini pada tahun 1725.

Karena negeri/perkampungan tersebut belum memiliki nama, maka opo-opo berunding mencari nama yang sesuai dan cocok untuk perkampungan yang baru ini. Berhubung negeri/perkampungan yang ada pada saat itu di bagian Barat desa yang saat itu sulit untuk mendapatkan air sehingga perkampungan dipindahkan dibagian Timur dekat aliran sungai yang saat ini disebut Riping (Terjal). Sungai tersebut dilatar belakangi dengan bebatuan dengan sebuah lobang (Goa). Aliran sungai itulah yang dinamakan oleh Opo-Opo dibawah pimpinan Opo Maapi "Timulap" sebagai simbol Nama Negeri Tulap pada tahun 1725 .

\section{Letak Geografis}

Wanua Tulap merupakan salah satu desa yang berada di wilayah Kecamatan Kombi di bagian Tengah Kabupaten Minahasa di Pantai Timur. Terletak di pegunungan Lembean Selatan $\pm 6 \mathrm{~km}$ dari pantai laut Maluku dan \pm 450 meter tinggi dari permukaan laut, yang posisinya $\pm 10^{\circ}$ Lintang Utara dan $125^{\circ}$ Bujur Timur di ujung Selatan Kecamatan Kombi. Sesuai kesepakatan lewat musyawarah dan mufakat maka ditetapkanlah waktu terbentuknya Wanua Tulap adalah pada tanggal 31 Oktober 1972 sesuai datadata yang ada.

Wanua Tulap diapit dua buah sungai dengan posisinya yang pertama Sungai Kawis \pm $1,5 \mathrm{~km}$ dari pemukiman penduduk melintasi 2 perbukitan kesebelah Utara, yang mengalir dari Barat ke Timur. Kedua Sungai Kamenti $\pm 1,5 \mathrm{~km}$ dari pemukiman penduduk melintasi dua perbukitan kesebelah Selatan yang mengalir dari Barat ke Timur.

Ditengah pemukiman penduduk terdapat sebuah pohon yang sudah berumur ribuan tahun yang dibawahnya mempunyai mata air yang sampai sekarang ini masih menjadi sumber mata air utama warga yang disebut "Kebuan". Mempunyai luas wilayah 1235 ha, dengan pembagian tanahnya dilihat dari fungsinya yaitu Tanah kering yang terdiri atas Pekarangan/Bangunan 15 ha, Tegal/Perkebunan /Pertanian 807 ha. Yang kedua Tanah Basah yaitu kolam 2 ha, ketiga Hutan Rakyat 2 ha, ke empat Tanah keperluan fasilitas umum terdiri atas Lapangan Olah Raga 5 ha, Pekuburan 3 ha, dan terakhir lain-lain (tanah tandus/tanah pasir) 404 ha.

Batas-batas yang mengelilingi Wanua Tulap yaitu :

- Sebelah Utara berbatasan dengan Perkebunan Desa Lalumpe dan Kayubesi Kecamatan Kombi

- Sebelah Timur berbatasan dengan Pantai Laut Maluku dan Perkebunan Desa Kapataran Kecamatan Lembean Timur,

- Sebelah Selatan berbatasan dengan Perkebunan Desa Kapataran Kecamatan Lembean Timur,

- Sebelah Barat berbatasan dengan Perkebunan Desa Seretan kecamatan Lembean Timur.

Keadaan topografi dan iklim Desa Tulap yaitu datar sampai berombak sebanyak $45 \%$ sedangkan sisanya berombak sampai berbukit sebanyak 55\%. Suhu maksimum desa Tulap $31^{\circ}$ dan memiliki suhu minimum $26^{\circ}$.

\section{Keadaan Penduduk}

Jumlah penduduk yang ada di Desa Tulap Kecamatan Kombi sebanyak 1157 jiwa, yang terdiri atas 356 kepala keluarga. Keadaan penduduk di Desa Tulap dibagi berdasarkan jenis kelamin, tingkat pendidikan, dan pekerjaan. Tabel 3 menunjukkan jumlah penduduk menurut jenis kelamin di Desa Tulap. Tabel 4 menunjukkan jumlah penduduk berdasarkan tingkat pendidikan. Tabel 5 menunjukkan jumlah penduduk berdasarkan pekerjaan.

Tabel 3. Jumlah Penduduk menurut Jenis Kelamin di Desa Tulap

\begin{tabular}{llcr}
\hline No & Jenis & Jumlah (jiwa) & Persentase (\%) \\
& Kelamin & & \\
\hline 1. & Laki-laki & 584 & 50,48 \\
2. & Perempuan & 573 & 49,52 \\
\hline & Total & 1157 & 100 \\
\hline
\end{tabular}

Sumber: Laporan Desa Tulap 2017

Tabel 3 menunjukkan bahwa jumlah penduduk berjenis kelamin laki-laki $(50,48 \%)$ lebih besar dari pada penduduk dengan jenis kelamin perempuan $(49,52 \%)$. 
Tabel 4. Jumlah Penduduk menurut Tingkat Pendidikan

\begin{tabular}{llcr}
\hline No & $\begin{array}{c}\text { Tingkat } \\
\text { Pendidikan }\end{array}$ & Jumlah & Persentase (\%) \\
\hline 1. & Tidak lulus SD & 0 & 0 \\
2. & SD & 267 & 29,83 \\
3. & SMP & 157 & 17,54 \\
4. & SMA & 398 & 44,46 \\
5. & D1 & 0 & 0 \\
6. & D2 & 8 & 0,89 \\
7. & D3 & 5 & 0,56 \\
8. & S1 & 56 & 6,26 \\
9. & S2 & 3 & 0,34 \\
10. & S3 & 1 & 0,12 \\
\hline & Total & 895 & 100 \\
\hline
\end{tabular}

Sumber : Laporan Desa Tulap 2017

Tabel 4 menunjukkan bahwa tingkat pendidikan penduduk di Desa Tulap didominasi oleh tingkat SMA sebanyak 44,46\%, kemudian tingkat SD sebanyak 29,83\%, tingkat SMP dengan 17,54\%, dan Perguruan Tinggi sebanyak $8,17 \%$. Tabel 4 menunjukkan bahwa tingkat pendidikan penduduk di Desa Tulap didominasi oleh tingkat SMA sebanyak $44,46 \%$, kemudian tingkat SD sebanyak $29,83 \%$, tingkat SMP dengan $17,54 \%$, dan Perguruan Tinggi sebanyak $8,17 \%$.

Tabel 5 menunjukkan bahwa sebagian besar penduduk Desa Tulap berprofesi sebagai petani dengan jumlah 421 orang atau $57,51 \%$ dari penduduk yang ada, hal ini menunjukkan bahwa perekonomian masih bersifat agraris yang ditunjukan oleh banyaknya penduduk yang bekerja pada sektor pertanian.

Tabel 5. Penduduk menurut Pekerjaan di Desa Tulap

\begin{tabular}{llcr}
\hline No & Mata Pencaharian & Jumlah & Persentase (\%) \\
\hline 1. & Petani & 421 & 57,51 \\
2. & Guru & 28 & 3,82 \\
3. & PNS & 30 & 4,09 \\
4. & Pegawai Swasta & 57 & 7,78 \\
5. & POLRI & 2 & 0,27 \\
6. & Pensiunan & 41 & 5,60 \\
7. & Peternak & 20 & 2,74 \\
8. & Wiraswasta & 48 & 6,56 \\
9. & Pengrajin/Industri/Meubel & 67 & 9,16 \\
10. & Penjahit & 7 & 0,96 \\
11. & Tukang/Bas & 11 & 1,51 \\
\hline \multicolumn{2}{r}{ Total } & 732 & 100 \\
\hline
\end{tabular}

Sumber : Laporan Desa Tulap 2017

\section{Perekonomian Desa Tulap}

Tanaman perkebunan memegang peranan penting dalam menunjang perekonomian warga desa Tulap. Selain tanaman perkebunan, adapula tanaman pertanian lainnya serta penghasilan warga yang berprofesi sebagai Pegawai Negeri/Swasta, Tukang (batu, kayu, jahit), pengrajin anyaman juga sebagai wiraswasta yang menunjang perekonomian desa. Disamping itu, terdapat potensi pariwisata dan budaya yakni Objek Wisata Pantai Tulap, Lokasi Asal Mula Sejarah Tulap (Riping), Tarian Maengket, Koor dan Vocal Grup.

Komoditas Unggulan yang berada di Desa Tulap terbagi atas tanaman Pertanian dan Perkebunan. Komoditi tanaman Pertanian yaitu Jagung, Kacang Tanah, Padi Ladang, Umbiumbian, Cabe, dan Tomat. Sedangkan komoditi tanaman perkebunan di Desa Tulap ditunjukkan dalam Tabel 6 di bawah ini.

Tabel 6. Komoditi Tanaman Perkebunan Desa Tulap

\begin{tabular}{llcc}
\hline No & Komoditi & $\begin{array}{c}\text { Berbuah } \\
\text { (Pohon) }\end{array}$ & $\begin{array}{c}\text { Belum Berbuah } \\
\text { (Pohon) }\end{array}$ \\
\hline 1. & Cengkeh & 120.000 & 90.500 \\
2. & Kelapa & 150.500 & 128.500 \\
3. & Vanili & 500 & 200 \\
4. & Pala & 280 & 300 \\
5. & Kopi & 150 & 120 \\
6. & Buah-buahan & 87.500 & 75.000 \\
\hline
\end{tabular}

Sumber : Laporan Desa Tulap, 2017

\section{Karakteristik Petani Cengkeh Desa Tulap}

Karakteristik petani cengkeh digunakan untuk mengetahui keragaman dari responden petani cengkeh berdasarkan jenis kelamin, jenis usaha tani lainnya dan jenis usaha pekerjaan lain. Hal tersebut diharapkan dapat memberikan gambaran yang cukup jelas mengenai kondisi dari responden dan kaitannya dengan masalah dan tujuan penelitian.

1. Berdasarkan Jenis Kelamin

Petani Cengkeh berdasarkan jenis kelamin. Tabel 7 menunjukkan bahwa 100\% responden berjenis kelamin laki-laki. Hal ini disebabkan petani cengkeh di desa Tulap didominasi oleh laki-laki karena kondisi perkebunan cengkeh lebih membutuhkan tenaga laki-laki. 
Tabel 7. Petani Cengkeh Berdasarkan Jenis Kelamin

\begin{tabular}{lcr}
\hline Jenis Kelamin & Jumlah (jiwa) & Persentase (\%) \\
\hline Laki-Laki & 46 & 100 \\
Perempuan & 0 & 0 \\
\hline Total & 46 & 100 \\
\hline
\end{tabular}

Sumber data : Diolah dari data primer, 2018

2. Berdasarkan Jenis Usaha Tani lainnya

Keragaman jenis usaha tani lainnya petani cengkeh. Tabel 8 menunjukkan bahwa komoditi kelapa merupakan tanaman yang paling banyak di tanam oleh petani cengkeh. Komoditi kelapa memiliki persentase terbesar yaitu $41,30 \%$, kelapa dan pala sebesar $17,40 \%$ serta kelapa dan jagung sebesar 10,88\%. Sedangkan komoditi tanaman kacang tanah dan caberawit merupakan tanaman yang paling sedikit di tanam oleh petani cengkeh, yakni rata-rata sebesar $2,17 \%$.

Tabel 8. Jenis Usaha Tani Lainnya Petani Cengkeh

\begin{tabular}{llcr}
\hline No & $\begin{array}{l}\text { Usaha Tani } \\
\text { Lainnya }\end{array}$ & Jumlah (jiwa) & Persentase (\%) \\
\hline 1. & Kelapa & 19 & 41,30 \\
2. & Pala & 5 & 10,87 \\
3. & Jagung & 4 & 8,70 \\
4. & Cabe Rawit & 1 & 2,17 \\
5. & Kacang Tanah & 1 & 2,17 \\
6. & Kelapa, Pala & 8 & 17,40 \\
7. & Kelapa, Jagung & 5 & 10,88 \\
8. & Pala, Jagung & 1 & 2,17 \\
9. & Jagung, Cabe & 1 & 2,17 \\
& Rawit & & 2,17 \\
10. & Kacang Tanah, & 1 & 100 \\
\hline & Cabe Rawit & & \\
\hline & Total & 46 & \\
\hline
\end{tabular}

Sumber data: Diolah dari data primer, 2018

3. Berdasarkan Jenis Mata Pencaharian Lain

Keragaman jenis mata pencaharian lainnya petani cengkeh. Tabel 9 menunjukkan bahwa sebesar $56,52 \%$ petani cengkeh tidak memiliki usaha pekerjaan lainnya. Hal ini membuktikan hampir semua petani cengkeh masih bergantung pada penghasilan usaha tani.

Petani cengkeh di Desa Tulap memiliki rata-rata jam kerja selama 5 jam per hari. Biasanya lama hari kerja petani rata-rata 5 hari dalam seminggu, yang berarti terdapat kurang lebih 20 hari kerja dalam sebulan atau 240 hari kerja selama setahun. Petani cengkeh di Desa Tulap memiliki 1200 jam kerja dalam satu tahun. Akumulasi waktu kerja ini sepenuhnya dipergunakan petani untuk aktivitas bertani cengkeh beserta komoditas tanaman lainnya.

Tabel 9. Jenis Mata Pencaharian Lainnya Petani Cengkeh

\begin{tabular}{llcr}
\hline No & \multicolumn{1}{c}{$\begin{array}{c}\text { Mata } \\
\text { Pencaharian } \\
\text { Lainnya }\end{array}$} & $\begin{array}{c}\text { Jumlah } \\
\text { (jiwa) }\end{array}$ & Persentase (\%) \\
\hline 1. & Tidak ada & 26 & 56,52 \\
2. & Perangkat Desa & 1 & 2,17 \\
3. & Perangkat Desa, & 1 & 2,17 \\
& Pangkas Rumput & & \\
4. & Perangkat Desa, & 1 & 2,17 \\
& Pedagang & & \\
5. & Perangkat Desa, & 1 & 2,17 \\
& Nelayan & & 6,52 \\
6. & Pangkas Rumput & 3 & 6,52 \\
7. & Sopir & 3 & 2,17 \\
8. & Pandai Besi & 1 & 4,35 \\
9. & Pengusaha & 2 & 2,17 \\
10. & Panjat Kelapa & 1 & 4,36 \\
11. & Pertukangan & 2 & 8,71 \\
12. & Ojek & 4 & 100 \\
\hline & Total & 46 &
\end{tabular}

Sumber data : Diolah dari data primer, 2018

\section{Karakteristik Rumah Tangga Petani Cengkeh Desa Tulap}

Penduduk Desa Tulap memiliki mata pencaharian terbanyak sebagai petani. Berdasarkan Laporan tahunan Desa Tulap (2017), rumah tangga petani berjumlah 249 rumah tangga. Rumah tangga petani cengkeh yang menanam komoditi lain tersebar pada 154 rumah tangga. Dalam penelitian ini, rumah tangga petani cengkeh yang diteliti sebanyak 46 rumah tangga dengan jumlah anggota rumah tangga sebanyak 156 jiwa. Rata-rata anggota rumah tangga petani cengkeh yang bekerja selain kepala keluarga ialah berjumlah 1 orang.

Anggota rumah tangga petani cengkeh memiliki mata pencaharian yang beragam yaitu pedagang, PNS, pensiunan, pensiunan dan penjahit, swasta, pengrajin, ojek, pemilik warung dan tidak memiliki mata pencaharian. Tabel 10 di bawah ini menunjukkan jenis mata pencaharian anggota rumah tangga petani cengkeh di Desa Tulap. 
Tabel 10 menunjukkan bahwa anggota rumah tangga petani cengkeh yang berkontribusi hanya 21 anggota keluarga dari 46 rumah tangga petani cengkeh. Anggota rumah tangga petani yang memiliki mata pencaharian terdiri dari istri atau anak pada usia produktifitas kerja.

Tabel 10. Jenis Mata Pencaharian Anggota Rumah Tangga

\begin{tabular}{|c|c|c|c|}
\hline \multicolumn{4}{|c|}{ Petani Cengkeh di Desa Tulap } \\
\hline No & $\begin{array}{l}\text { Mata } \\
\text { Pencaharian }\end{array}$ & Jumlah (RT) & Persentase (\%) \\
\hline 1. & Pedagang & 6 & 5,45 \\
\hline 2. & PNS & 6 & 5,45 \\
\hline 3. & Pensiunan & 1 & 0,91 \\
\hline 4. & $\begin{array}{l}\text { Pensiunan dan } \\
\text { Penjahit }\end{array}$ & 1 & 0,91 \\
\hline 5. & Swasta & 2 & 1,82 \\
\hline 6. & Pengrajin & 1 & 0,91 \\
\hline 7. & Ojek & 1 & 0,91 \\
\hline 8. & Pemilik Warung & 3 & 2,73 \\
\hline & Subtotal & 21 & 19,09 \\
\hline & $\begin{array}{l}\text { tal Anggota Rumah } \\
\text { Tangga }\end{array}$ & 110 & \\
\hline
\end{tabular}

Sumber data : Diolah dari data primer, 2018

\section{Analisis Pendapatan Rumah Tangga Petani Cengkeh di Desa Tulap}

\section{Pendapatan Rumah Tangga Petani di Luar Usaha Tani}

Beberapa rumah tangga petani cengkeh di Desa Tulap juga memiliki sampingan mata pencaharian di luar usaha tani (non farm). Tabel 11 menunjukkan rata-rata pendapatan rumah tangga petani cengkeh di luar usaha tani (non farm) ialah Rp7.682.609/tahun. Data tersebut merupakan pendapatan yang bersumber dari hasil wawancara langsung dengan responden langsung.

Tabel 11. Rata-rata Pendapatan Rumah Tangga Petani di Luar

\begin{tabular}{llcr} 
No & $\begin{array}{l}\text { Mata } \\
\text { Pencaharian }\end{array}$ & $\begin{array}{c}\text { Rata-rata } \\
\text { Pendapatan } \\
\text { (Rp/bulan) }\end{array}$ & $\begin{array}{c}\text { Pendapatan Luar } \\
\text { Usaha } \\
\text { Tani (Rp/tahun) }\end{array}$ \\
\hline 1. & Perangkat Desa & 750.000 & 9.000 .000 \\
2. & Nelayan & 3.000 .000 & 36.000 .000 \\
3. & Pedagang & 1.000 .000 & 12.000 .000 \\
4. & Pangkas Rumput & 1.200 .000 & 14.400 .000 \\
5. & Sopir & 1.200 .000 & 14.400 .000 \\
6. & Pandai Besi & 500.000 & 6.000 .000 \\
7. & Pengusaha & 3.500 .000 & 42.000 .000 \\
8. & Panjat Kelapa & 2.400 .000 & 28.800 .000 \\
9. & Pertukangan & 2.000 .000 & 24.000 .000 \\
10. & Ojek & 1.200 .000 & 14.400 .000 \\
11. & PNS & 5.000 .000 & 60.000 .000 \\
12. & Pensiunan & 3.000 .000 & 36.000 .000 \\
13. & Penjahit & 600.000 & 7.200 .000 \\
14. & Swasta & 2.100 .000 & 25.200 .000 \\
15. & Pengrajin & 200.000 & 2.400 .000 \\
16. & Pemilik Warung & 1.800 .000 & 21.600 .000 \\
\hline & Rata-rata & 640.217 & 7.682 .609 \\
\hline
\end{tabular}

Sumber data: Diolah dari data primer, 2018

\section{Analisis Sumber Pendapatan Rumah Tangga Petani Cengkeh}

a. Petani cengkeh di Desa Tulap memiliki empat jenis sumber pendapatan yaitu

1) Pendapatan dari usaha tani cengkeh ditambah pendapatan usaha tani lain ditambah pendapatan luar usaha tani dan ditambah pendapatan anggota keluarga (PC+PUTL+PLUT+PAK).

2) Pendapatan dari usaha tani cengkeh ditambah pendapatan usaha tani lain dan ditambah pendapatan luar usaha tani (PC+PUTL+PLUT). Ketiga terdiri atas pendapatan usaha tani cengkeh ditambah pendapatan usaha tani lain (PC+PUTL). Keempat yaitu pendapatan usaha tani cengkeh ditambah pendapatan usaha tani lain dan ditambah pendapatan anggota keluarga (PC+PUTL+PAK).

Keterangan:

PC = Pendapatan dari Usaha Tani Cengkeh

PUTL = Pendapatan Usaha Tani Lain PLUT = Pendapatan Luar Usaha Tani PAK $=$ Pendapatan Anggota Keluarga

Tabel 12 menunjukkan pendapatan rumah tangga petani cengkeh yang memenuhi empat sumber pendapatan yaitu usaha tani cengkeh, usaha tani lainnya, pendapatan di luar usaha tani dan pendapatan dari anggota keluarga. Berdasarkan hasil penelitian, terdapat 15,22\% petani yang memenuhi empat sumber pendapatan tersebut dengan rata-rata total pendapatan rumah tangga pertahunnya Rp.113.476.641.

Tabel 12. Total pendapatan rumah tangga petani cengkeh yang memperoleh penghasilan dari PC+PUTL+PLUT+PAK

\begin{tabular}{llrr}
\hline No & Nama & $\begin{array}{c}\text { Total Pendapatan } \\
\text { Rumah Tangga } \\
\text { Pertahun (Rp) }\end{array}$ & $\begin{array}{r}\text { Persentase } \\
(\mathbf{\%})\end{array}$ \\
\hline 1. & Fuldi Pakasi & 81.150 .000 & \\
2. & Mecky Wenas & 53.125 .000 & \\
3. & Jantje F. Lasut & 196.946 .489 & \\
4. & Oldy Rantung & 150.650 .000 & 15,22 \\
5. & Wenny Lasut & 118.250 .000 & \\
6. & Reifi Iyono & 97.475 .000 & \\
7. & Lando & 96.740 .000 & \\
& Mamahit & & 15,22 \\
\hline
\end{tabular}

Sumber data: Diolah dari data primer 2018 
Tabel 13 menunjukkan besar hasil pendapatan petani cengkeh yang memiliki tiga sumber pendapatan yaitu dari usaha tani cengkeh, usaha tani lainnya, dan luar usaha tani. Berdasarkan hasil penelitian di Desa Tulap terdapat 28,26\% rumah tangga petani yang memenuhi tiga sumber pendapatan tersebut dengan total pendapatan rumah tangga pertahunnya yaitu Rp. 41.288.808.

Tabel 13. Total pendapatan rumah tangga petani cengkeh yang memperoleh penghasilan dari PC+PUTL+PLUT

\begin{tabular}{clrc}
\hline No & \multicolumn{1}{c}{ Nama } & $\begin{array}{c}\text { Total Pendapatan } \\
\text { Rumah Tangga } \\
\text { Pertahun (Rp) }\end{array}$ & $\begin{array}{c}\text { Persentase } \\
(\%)\end{array}$ \\
\hline 1 & Yoosee Lompoliu & 39.050 .000 & \\
2 & Jelky Wenas & 27.700 .000 & \\
3 & Michael Pakasi & 31.200 .000 & \\
4 & Lian Lasut & 32.925 .000 & \\
5 & Ricky Mewoh & 44.312 .500 & \\
6 & Jembry Mewoh & 40.032 .000 & \\
7 & Rifel Kerap & 36.250 .000 & 28,26 \\
8 & Efraim Walujan & 36.250 .000 & \\
9 & Mayfel Mewoh & 69.785 .000 & \\
10 & Jemmy Kerap & 41.200 .000 & \\
11 & Glen Lasut & 36.400 .000 & \\
12 & Andris Jacobis & 52.200 .000 & \\
13 & Steven Kerap & 49.450 .000 & \\
\hline \multicolumn{4}{c}{ Rata-rata } \\
\hline
\end{tabular}

Sumber data : Diolah dari data primer, 2018

Tabel 14 menunjukkan besar hasil pendapatan petani cengkeh yang memiliki dua sumber pendapatan yaitu dari usaha tani cengkeh, usaha tani lainnya. Berdasarkan hasil penelitian di Desa Tulap terdapat 15,22\% rumah tangga petani yang memenuhi dua sumber pendapatan tersebut dan memeiliki total pendapatan rumah tangga pertahun sebesar Rp. 66.868.784.

Tabel 14. Total pendapatan rumah tangga petani cengkeh yang memperoleh penghasilan dari PC+PUTL

\begin{tabular}{llrr}
\multicolumn{5}{c}{ dari PC+PUTL } \\
\hline No & Nama & $\begin{array}{c}\text { Total } \\
\text { Pendapatan } \\
\text { Rumah Tangga } \\
\text { Pertahun (Rp) }\end{array}$ & Persentase (\%) \\
& & $178,246,489$ & \\
\hline 1 & Jonatan & $22,800,000$ & \\
& Palilingan & $20,300,000$ & 15,22 \\
2 & Jefrie Senduk & $50,475,000$ & \\
3 & Tomi Pesiwarisa & $123,875,000$ & \\
4 & Raimont Mewoh & $34,425,000$ & 15,22 \\
5 & Rio Senduk & $37,960,000$ & \\
6 & Joppy Mamahit & 66.868 .784 \\
7 & Jefri Tampa & & \\
\hline \multicolumn{5}{l}{ Rata-rata } &
\end{tabular}

Tabel 15 menunjukkan besar pendapatan petani cengkeh yang memiliki 3 sumber pendapatan yaitu dari usaha tani cengkeh, pendapatan usaha tani lain, dan pendapatan dari anggota rumah tangga. Berdassrkan hasil penelitian di Desa Tulap terdapat 41,30\% rumah tangga petani yang memenuhi tiga sumber pendapatan tersebut dan memiliki total pendapatan rumah tangga pertahun sebesar Rp. 55.892 .196 .

Tabel 15. Total pendapatan rumah tangga petani cengkeh yang memperoleh penghasilan dari PC+PUTL+PAK

\begin{tabular}{clcc}
\hline No & \multicolumn{1}{c}{ Nama } & $\begin{array}{c}\text { Total } \\
\text { Pendapatan } \\
\text { Rumah Tangga } \\
\text { Pertahun (Rp) }\end{array}$ & $\begin{array}{c}\text { Persentase } \\
(\boldsymbol{\%})\end{array}$ \\
\hline 1 & Farry Pakasi & $96,550,000$ & \\
2 & Rifki Pakasi & $40,650,000$ & \\
3 & Piet Pesiwarisa & $42,081,683$ & \\
4 & Rudi Togas & $25,150,000$ & \\
5 & Bobby Lasut & $93,875,000$ & \\
6 & Ponggawa Lompoliu & $38,600,000$ & \\
7 & Recky Senduk & $49,850,000$ & \\
8 & Franky Sepang & $67,375,000$ & \\
9 & Fontje Tangkulung & $64,450,000$ & \\
10 & Champion Lomboan & $54,025,000$ & 41,30 \\
11 & Marfi Pangkola & $70,125,000$ & \\
12 & Refli Mamahit & $82,275,000$ & \\
13 & Jembri Kerap & $29,725,000$ & \\
14 & Arter Mamahit & $24,850,000$ & \\
15 & Efendy Lompoliu & $44,900,000$ & \\
16 & Moudy Walujan & $41,331,683$ & \\
17 & FrangklyR.Lomboan & $52,100,000$ & \\
18 & Jecky Lomboan & $47,081,683$ & \\
19 & Herry Pakasi & $96,956,683$ & \\
\hline & Rata-rata & 55.892 .196 & 41,30 \\
\hline
\end{tabular}

Sumber data : Diolah dari data primer, 2018

\section{KESIMPULAN DAN SARAN}

Kesimpulan

Hasil penelitian menunjukkan bahwa sumber pendapatan rumah tangga petani cengkeh di Desa Tulap Kecamatan Kombi terdiri dari usaha tani cengkeh, usaha tani lainnya, dan mata pencaahariam di luar usaha tani. Mata pencaharian di luar usaha tani terbagi atas pendapatan petani dan anggota rumah tangga petani di luar usaha tani. 
Penelitian menunjukkan pendapat-an rumah tangga petani cengkeh tertinggi di peroleh oleh rumah tangga petani yang memenuhi empat sumber pendapatan yaitu dari usaha tani cengkeh, usaha tani lainnya, pendapatan di luar usaha tani dan pendapatan anggota keluarga yaitu dengan rata-rata sebesar Rp. 113.476.641 per tahun dengan persentase $15,22 \%$. Hal ini membuktikan apabila petani cengkeh memiliki usaha tani lainnya, memiliki pekerjaan di luar usaha tani, dan anggota rumah tangganya memiliki pekerjaan dan turut berkontribusi dalam pendapatan rumah tangga maka rumah tangga tersebut akan semakin sejahtera.

\section{Saran}

Petani diharapkan dapat mengelola pendapatan rumah tangga dengan baik dan mampu memenuhi semua sumber pendapatan baik dari usaha tani cengkeh, usaha tani lainnya, luar usaha tani, dan pendapatan anggota rumah tangga agar dapat meningkatkan kesejahteraan ekonomi rumah tangga petani dan Desa Tulap.

\section{DAFTAR PUSTAKA}

Badan Pusat Statistik (BPS). 2016. Kabupaten Minahasa Dalam Angka 2016. Katalog 1102001.7102.menunjukkan

Daniel, M. 2002. Pengantar Ekonomi Pertanian. Bumi Aksara. Jakarta.

Dinas Pertanian Kabupaten Minahasa. 2016. Badan Pusat Statistik (BPS). Kabupaten Minahasa.

Laporan Desa Tulap. 2017. Pemerintah kabupaten Minahasa Kecamatan Kombi Wanua Tulap.

Nasution, 2013. Struktur Pendapatan dan Pengeluaran Rumah Tangga Petani Karet di Desa Sel Tonang Kecamatan Kampar Utara Kabupaten Kampar

Saragih B. 2004. Membangun Pertanian Perspektif Agribisnis. Penebar Swadaya. Bogor.

Wahyudi. 2009. Formasi dan Struktur Gerakan Sosial Petani: Studi Kasus Gerakan Reklaiming/Penjarahan Atas Tanah PTPN XII Kalibakar Malang Selatan. Jurnal UMM. 